\title{
原著
}

\section{頭蓋内占拠性病変における 経頭蓋超音波断層法画像診断の有用性とその限界}

\author{
長谷川 譲 \\ 東京慈恵会医科大学 脳神経外科
}

\section{Usefulness of Transcranial Ultrasound Imaging for Intracranial Space Occupied Lesion}

Yuzuru HASEGAWA

Department of Neurosurgery, Jikei University School of Medicine (Received 19 August 1992, Accepted 2 October 1992)

\begin{abstract}
We tried to evaluate the usefulness of the transcranial color flow imaging (TCFI) as a noninvasive imaging method for intracranial space occupied lesion (I-SOL).

METHOD-TCFI (ATL, ULTRAMARK $9^{\circledR}, 2.25 \mathrm{MHz}$ phazed arrey, $90^{\circ}$ sector scan) was applied from the bitemporal "acoustic window" to 22 meningiomas, 12 pituitary adenomas, 5 gliomas, 1 intraventricular tumor, 4 arteriovenous malformations (AVM), 7 intracerebral hematomas (ICH), 8 chronic subdural hematomas (CSH), 2 acute epidural hematomas (AEH), and 1 pediatric arachnoid cyst. RESULT-We were able to detect 12 meningiomas, 7 adenomas, 1 cystic glioma, 1 ventricular tumor, 2 AVMs, 6 ICHs, 6 CSHs, $2 \mathrm{AEHs}$, and 1 arachnoid cyst, as clearly defined lesions on B-mode images.

It was difficult to visualize the region of the posterior fossa. Frontal and high convexity regions were also difficult to investigate. CONCLUSION-TCFI has great advantages: movability, noninvasiveness and blood flow detection factors. It provides an useful diagnostic method for the I-SOL.
\end{abstract}

Key words : TCD, TCFI, Ultrasound, Brain tumor, Arteriovenous malformation.

\section{1. はじめに}

人体に㧍ける超音波の利用の歴史は意外に古い。1942 年 Dussik らは脳室の同定のために超音波を初めて用い ている。 その後 1955 年 Leksel1 ${ }^{11}$ が 2 probe 法によるA モード脳 Midline Echo 法を確立, 無侵襲頭蓋内診断につ いての報告を行なった。しかし脳神経外科領域に打いて は, 検查対象が頭蓋骨という音響的遮蔽性の高い組織に よって囲まれているため, 他の諸藏器に比して画像診断 的意義は一時低下した. 1982 年 Aaslid ら²) は, 経頭蓋超 音波ドプラ血流測定法 $($ Transcranial Doppler $=$ TCD $)$ を
開発し, 超音波利用のリアルタイム頭蓋内血流動態モ二 夕が可能であると報告した。ささに Spencer，古幡らは， 低周波数の超音波を用いた頭蓋内 $\mathrm{B}$ モード撮影による 経頭蓋超音波カラードプラ法（Transcranial Color Flow Imaging $=\mathrm{TCFI}$ ）の実用化を成功させ，頭蓋内血流動態 測定において B モード画像上に血流を可視化すること の有用性を提唱した ${ }^{3)-5)}$. 今回筆者は, TCFI 法を頭蓋内 占拠性病変 (Intracranial Space Occupied Lesion=I -SOL）に対する無侵襲頭蓋内画像診断として施行, CTscan，MRI 等と比較検討し新たなる知見を得たので ここに報告する.

長谷川 譲：干 105 東京都港区西新橋 3-25-8 東京慈恵会医科大学脳神経外科.

Yuzuru HASEGAWA : Dept. of Neurosurgery, Jikei University School of Medicine, 3-25-8, Nishi-shinbashi, Minato-ku Tokyo 105. 


\section{2. 対象および方法}

当院脳外科症例に扔いて CT scan, MRI 等の他の画像 診断装置にてあらかじめ術前診断された I-SOL 全 70 例 に対し左右両側の側頭骨面より TCFI 検查を施行した. その内訳は, 䯣膜腫 22 例, 下垂体腺腫 12 例, 神経膠腫 8 例, 脳室内神経細胞腫 1 例, 松果体部腫痬 2 例, 脳動静 脈奇形 5 例, 高血圧性脳内出血 8 例, 急性硬膜外血腫 2 例, 慢性硬膜下血腫 9 例, 鞍上部クモ膜囊胞 1 例であっ た（なお，腫瘍例は髄膜腫 1 例，下垂体腺腫 1 例，松果 体部腫瘍 1 例を除き全症例術後病理検査にて確定診断さ れている).

使用機器は, ATL 社製 ULTRAMARK $9(2.25 \mathrm{MHz}$ phazed array probe, $90^{\circ}$ sector scan) を用いた。

$\mathrm{B}$ モード画像上，頭蓋内正常構造物 (大脳鎌，脳室，中 脳, 蝶形骨縁, 松果体部の石灰化等) を描出し, これら を目標として病変部を同定することを目的とした。検査 時, 走査方向は出来得る限り CT scan, MRI の構成画像 と一致させた。また $\mathrm{I}-\mathrm{SOL}$ 像の描出に続いて $2 \mathrm{D}-$

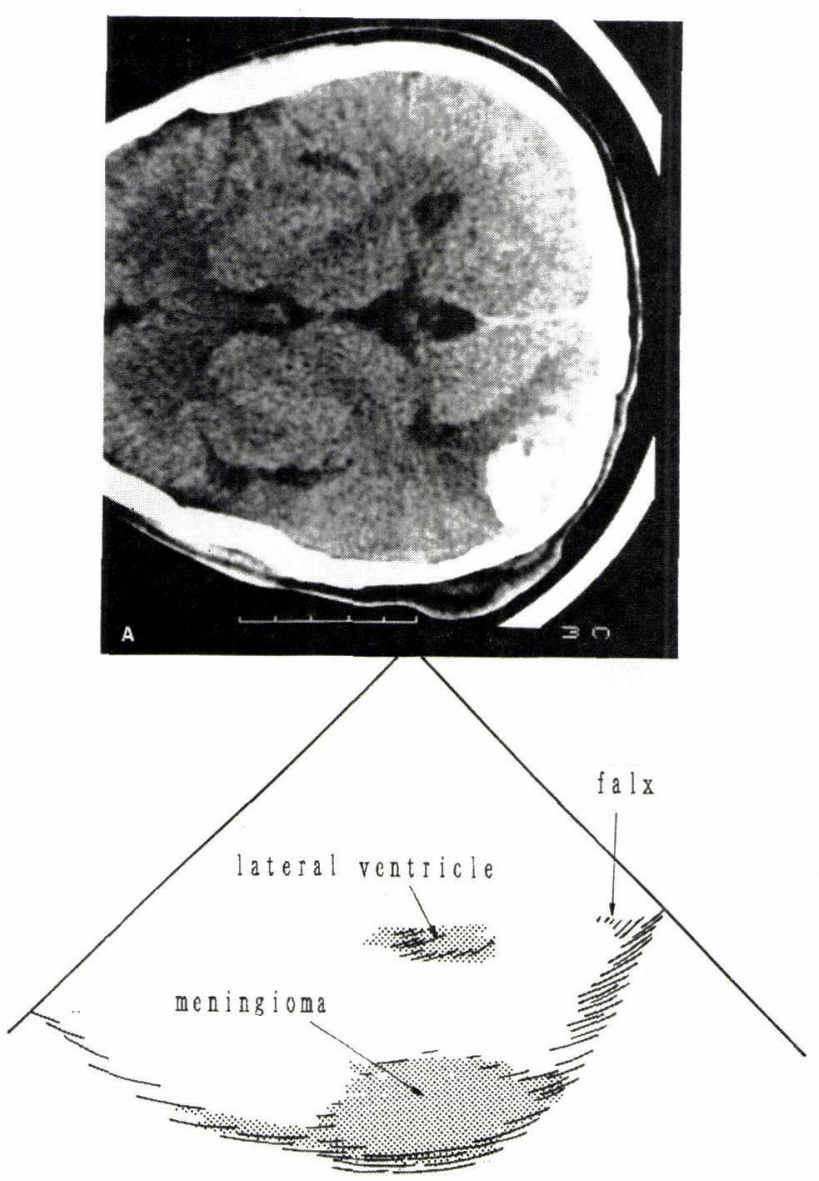

Table 1 Percentage of ability for the detection of middle cerebral artery.

\begin{tabular}{cccccccc}
\hline Age & $5 \sim 20$ & \multicolumn{2}{c}{$21 \sim 50$} & \multicolumn{2}{c}{$51 \sim$} \\
\hline Sex & $M$ & $F$ & $M$ & $F$ & & $M$ & $F$ \\
\hline No. of cases & 9 & 11 & 22 & 42 & 23 & 33 \\
\hline Ability (\%) & 100 & 100 & 77 & 71 & 52 & 45 \\
\hline & & & & & & & \\
& & & & & &
\end{tabular}

Doppler 画像にて 病変周辺の血流を探知する操作を繰 り返した。

検討事項としては以下の 2 点である.

（1）経頭蓋超音波断層による病変検出の可否

（2）病変部周辺の血流動態の評価

\section{3. 結 果}

これより代表症例を呈示しつつ結果について詳述す る.

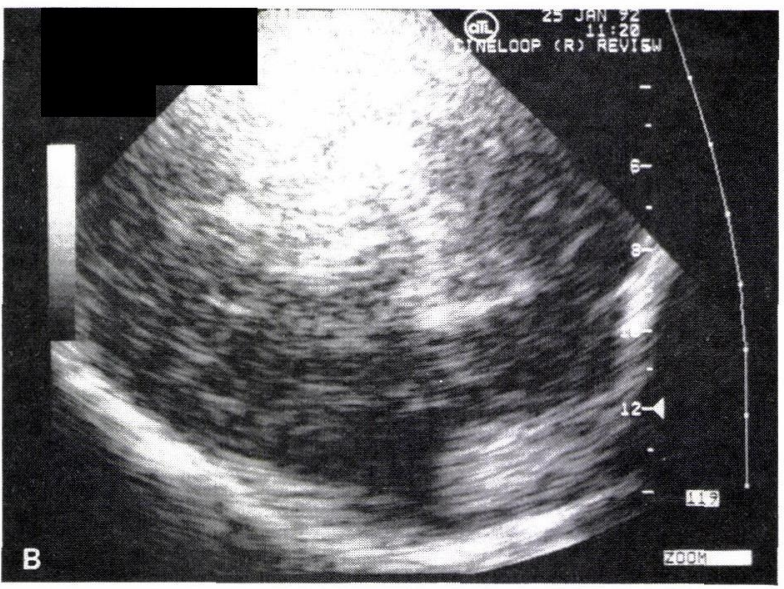

Fig. 1 30-year-old female. A, CT scan and schematic illustration demonstrating an occipital meningioma B, TCFI of the same patient, axial scanning plane. TCFI shows clear tumor shape and occipital bone. 

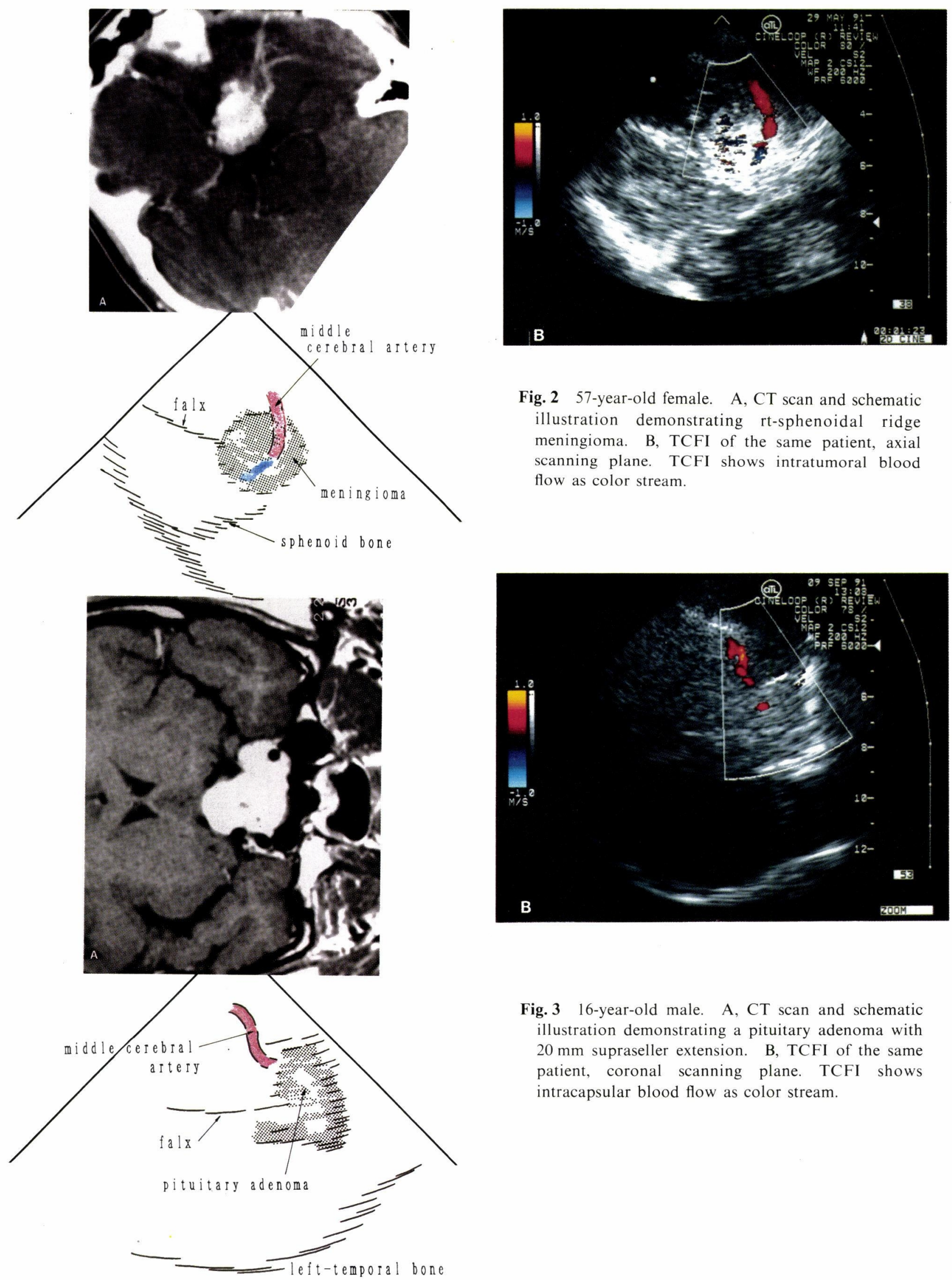

Fig. 2 57-year-old female. A, CT scan and schematic illustration demonstrating rt-sphenoidal ridge meningioma. B, TCFI of the same patient, axial scanning plane. TCFI shows intratumoral blood flow as color stream.

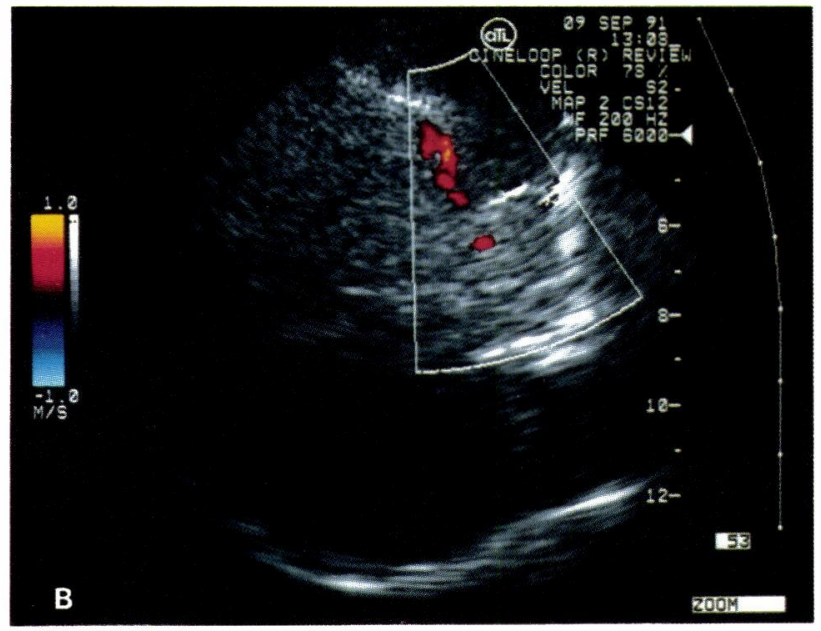

Fig. 3 16-year-old male. A, CT scan and schematic illustration demonstrating a pituitary adenoma with $20 \mathrm{~mm}$ supraseller extension. B, TCFI of the same patient, coronal scanning plane. TCFI shows intracapsular blood flow as color stream. 

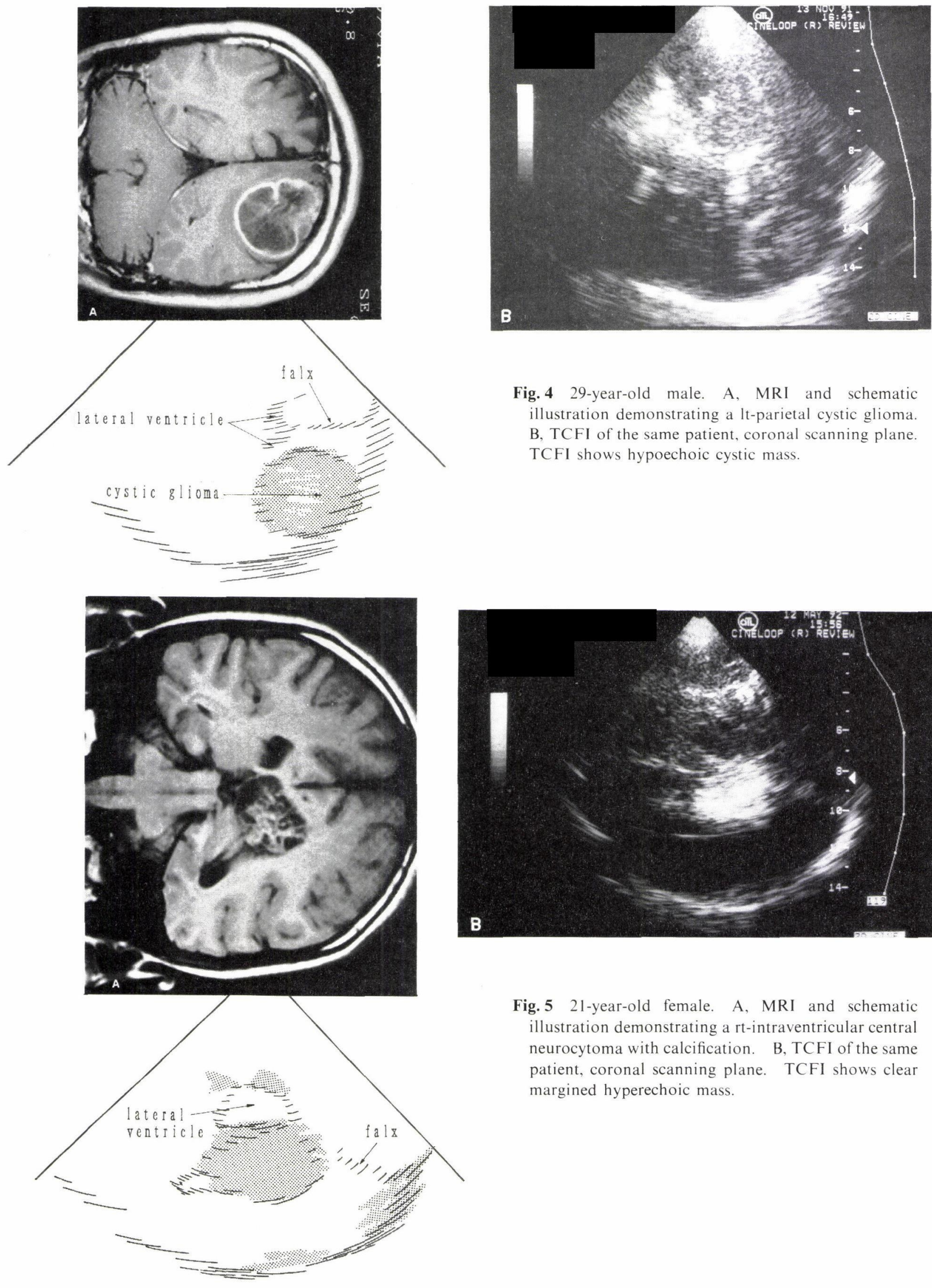

Fig. 4 29-year-old male. A, MRI and schematic illustration demonstrating a lt-parietal cystic glioma. $\mathrm{B}$, TCFI of the same patient, coronal scanning plane. TCFI shows hypoechoic cystic mass.

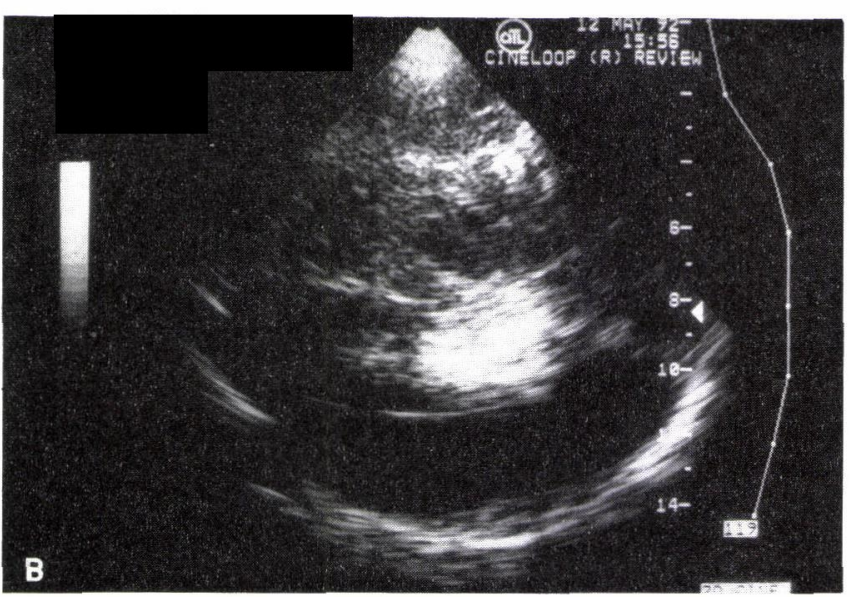

Fig. 5 21-year-old female. A, MRI and schematic illustration demonstrating a rt-intraventricular central neurocytoma with calcification. B, TCFI of the same patient, coronal scanning plane. TCFI shows clear margined hyperechoic mass. 

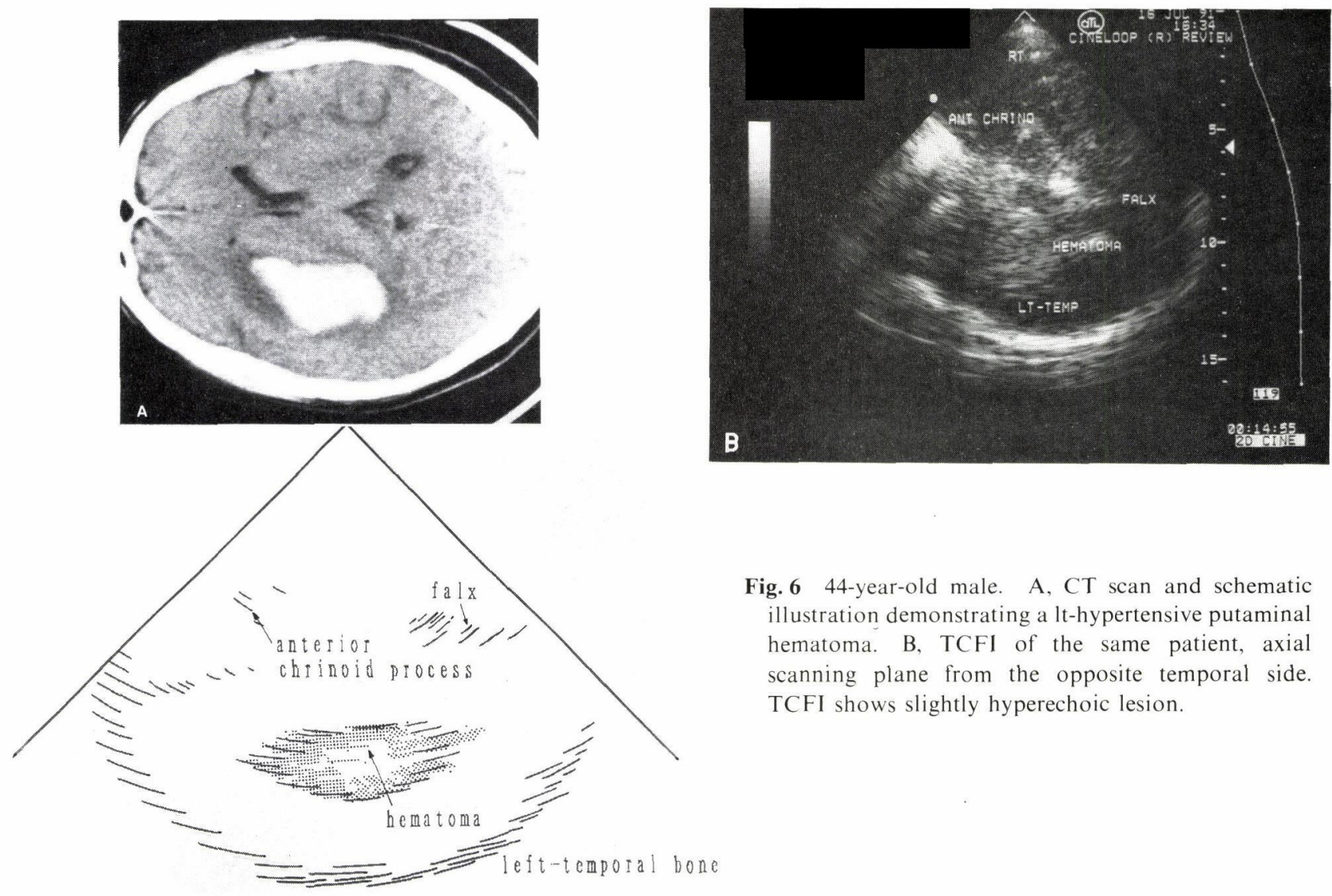

Fig. 6 44-year-old male. A, CT scan and schematic illustration demonstrating a lt-hypertensive putaminal hematoma. B, TCFI of the same patient, axial scanning plane from the opposite temporal side. TCFI shows slightly hyperechoic lesion.
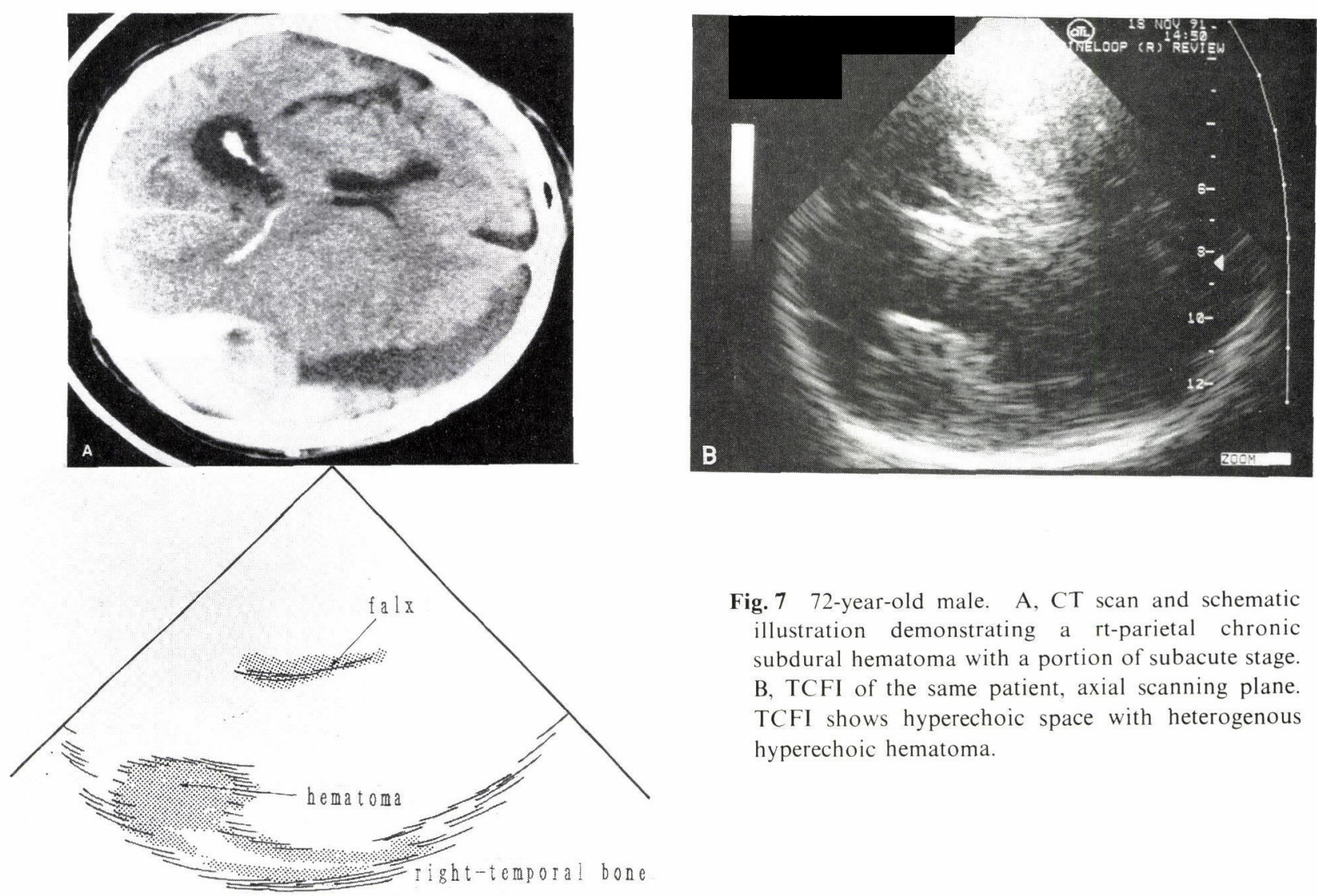

Fig. 7 72-year-old male. A, CT scan and schematic illustration demonstrating a rt-parietal chronic subdural hematoma with a portion of subacute stage. B, TCFI of the same patient, axial scanning plane. TCFI shows hyperechoic space with heterogenous hyperechoic hematoma. 

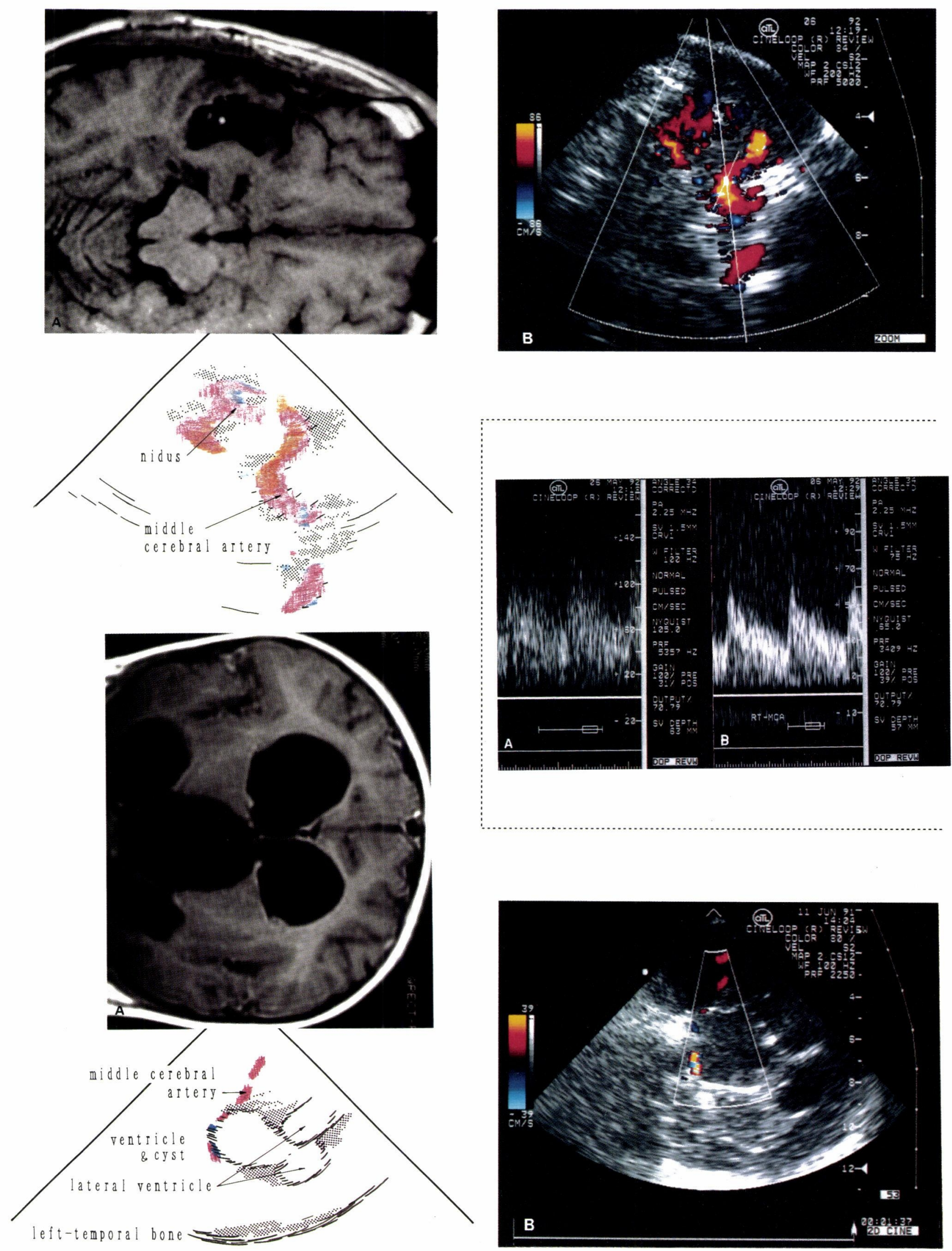


\section{3-1 中大脳動脈の描出率について}

頭蓋内構造物の描出能力を, 本検索に加えて当科にて 施行した全検索症例の中大脳動脈血流 2D-Doppler 画像 描出率で検討した. 結果は 20 歳以下では男女とも全例捕 捉可能であったが, 21 ～ 50 歳では男 $77 \%$ 女 71\%, 51 歳以 上では男 $52 \%$ 女 $45 \%$ の描出率であった. すなわち加齢に ておよび同世代では男性より女性にて上記描出能力は低 下する傾向であった Table 1). しかし, 頭蓋骨の超音波 透過の目安である対側側頭骨の描出については, 側頭面 上の 4力所の acoustic window 上5), いずれかの場所から 不充分ながらも描出可能であり, 占拠性病変に関しての 描出は血流の描出率より良好であった。

また頭蓋内構造が描出不可能（no window）であった 24 症例の CT scanを検討した結果, 側頭骨の厚さが 4 $\mathrm{mm}$ を越えるものが 14 症例, また側頭部の軟部組織の厚 さが $15 \mathrm{~mm}$ 以上のものは 9 例であった（4例で重複あ り).

\section{3-2 腫瘍性病変について}

骾膜腫全 22 例のうち超音波画像上腫瘍像を確認でき たものは13例である. 後頭蓋窩 3 例と no window で あった高齢者例あるいは中年女性例の 6 例はいずれも画 像上検索不可能であった。描出可能であった 13 例はいず れも hyperechoic (Fig. 1) で, 比較的 hypoechoic の脳実 質, 脳室, 髄液槽等と明らかに区別された。しかし, ト ルコ鞍近傍の直径 $15 \mathrm{~mm}$ 以下の髄膜腫は周辺の骨構造 物との区別は困難であった。前頭部または頭頂部高位の 3 例では画像構成上アーチファクトの混入が多かった. 2D-Doppler 画像上に血流の存在が確認されたものは 2 例だった。特に蝶形骨縁髄膜腫において coronal 方向の 走査で中頭蓋窩およびそれに接した腫瘍を示す円形の hyperechoic lesion が描出され, その中を貫通するように color flow stream が確認された（Fig. 2).

下垂体腺腫全 12 例のうち超音波画像上腺腫像を確認
できたものは 7 例であった. 撮像方向は coronal, axial の 比較にて前者が有用であった. 腺腫の内部 echo pattern は hyperechoic, hypoechoicいずれの症例も存在した (Fig. 3). Fig. 3 の症例では, 腺腫被膜の内側に内頝動脈 の走行が color flow で描出された. トルコ鞍内にのみ腺 腫が限局していたもの 3 例はその存在を画像上描出不可 能であり, 中年女性 2 例は傍卜ルコ鞍部の骨構造物と腺 腫を区別することが困難であった。 また鞍上部進展した 下垂体腺腫症例において腫瘍影の描出限界を検討した が, 冠状断方向のスキャンにて CT scan 計測上 $10 \mathrm{~mm}$ ま で画像上は描出可能であった。しかし, 超音波画像のみ で組織性状を精密に判別することは不可能であり, 周辺 の骨組織との境界を明確に分けることは困難であった.

神経膠腫全 8 例のうち腫瘍の存在が画像上同定可能で あったものは, 内部に cyst を伴っていた症例のみであっ た (Fig. 4).また脳室内 central neurocytoma と松果体部 腫瘍は, 内部の石灰化を中心として hyperechoic に描出 された（Fig. 5).

\section{3-3 血腫性病变について}

高血圧性脳内出血全 8 例のうち 7 例が描出可能であっ た. 血腫像の描出は同側からの検索より対側の側頭骨面 からのほうが容易な例もあった(Fig. 6). また描出画像の 多くは, 脳実質よりわずかに hyperechoic であったが, 病 期による血腫性状の判定は困難であった.

慢性硬膜下血腫全 9 例のうち 6 例が描出可能であっ た. 6 例中 2 例は血腫同側からの検索で脳表面の後退と 血腫による anechoic 領域を認めた. ただし頭蓋骨による 多重反射との鑑別は注意を要した．残り 4 例は頭頂部高 位に血腫本体が限局しており同側からの検索では死角域 で対側からのみ描出可能であった．亜急性血腫を伴った 慢性硬膜下血腫の 1 例ではほぼ CT scan像と同等の所 見が得られた (Fig. 7). 他のいずれの血腫も内部のエコー 信号としては hypoechoic で, 血腫と脳表との境界部で

\footnotetext{
Fig. 8

Fig. 9

Fig. 10

前ページ

困説明
}

Fig. 8 35-year-old male. A, CT scan and schematic illustration demonstrating a lt-parietal arteriovenous malformation. B, TCFI of the same patient, axial scanning plane. TCFI shows winding and enlarged artery, scrolled nidus.

Fig. 9 28-year-old male. A, Flow pattern of 1t-middle cerebral artery. B, Flow pattern of rt-middle cerebral artery. It shows differnt flow pattern.

Fig. 10 3-year-old boy. A, CTscan and schematic illustration demonstrating a suprasellar arachnoid cyst extending to the third ventricle. B, TCFI of the same patient, coronal scanning plane. TCFI shows dilatated ventricular system and fair cyst wall. 
hyperechoic な line が認められた。

急性硬膜外血腫は 2 例とも前述の慢性血腫例に類似し ており，内部のエコー信号は hypoechoic で，血腫と脳表 との境界部で hyperechoic な line が認められた。

\section{3-4 血管性病変について}

脳動静脈奇形全 5 例のうち 3 例で TCFI を用いた 2D Doppler 画像上異常血管の描出が可能であった（Fig. 8). 特に脳幹前面から小脳に拡がる nidus をもった症例 では大孔と環椎の間吵からの検索にて feeding arteryの 後下小脳動脈とそれに連なる nidus の一部が捉えられ た. さらに画像に加えて Doppler sonogram を用いるこ とで feeding artery, nidus, draining vein の正確な同定 が可能であった。描出不能中の 1 例は 2D-Doppler 画像 では病変本体の異常影は捕捉できなかったが，中大脳動 脈の血流パタンの著しい左右差を認め(Fig.9),もう 1 例 は血流成分はとらえられなかったが, nidus 内の粒状石 灰化の成分が点状 hyperechoic に描出された。

\section{3-5 小児くも膜䨳胞について}

大泉門閉鎖後の小児例に対しても，側頭面から検索す ることにより，鞍上部から第三脳室へ進展したくも膜囊 胞の描出が可能であった (Fig. 10). 小児は成人に比較し て脳室, 大脳鎌, 脈絡叢も鮮明に描出可能であった。 た 2D-Doppler 画像上中大脳動脈は $\mathrm{M}_{2}$ 区域まで追跡可 能であった。

\section{4. 考按}

近年，手術中に骨組織を除いた状況下で術中補助診断 の一環として7)-10)，また大泉門開存中の小児の頭蓋内検 索として，超音波画像の有用性を述べた報告が多く見ら れるようになった. しかし, 経頭蓋骨での頭蓋腔内検索 の有用性について言及したものは少ない。またそれらの ほとんどが正常例の呈示に留まり4)11)，わずかに脳動脈 瘤 ${ }^{1213)}$ と脳動静脈奇形14)において散見されるのみであ る. 著者は今回 TCFI 法を応用し頭蓋内占拠性病変に対 する超音波画像の有用性, 限界, そして今後の可能性に 関して考察する。

\section{4-1 腫瘍性病変における有用性について}

脳腫瘍の検索総数 43 例のうち 22 例で B-mode 画像上 描出可能であった。検出不能例のうち 8 例は no window のため, 3 例の後頭蓋窩髄膜腫および 3 例のトルコ鞍内 下垂体腺腫は音波の死角領域のため，また７例の神経膠 腫は境界不明確のため同定不可能であった。すなわち一 旦超音波が骨組織を透過しえた場合，死角領域に入らな ければ髄膜腫や下垂体腺腫のような境界明膫な腫瘍や石
灰化をきたしている腫痬の描出は極めて良好であった。 さらに，2D-Doppler 法を加えればリアルタイムの頭蓋 内血流の把握が可能となる。しかしながら神経膠腫につ いてはその組織学的特徵から高率に false negativeの症 例が存在し, 今後の課題である.

\section{4-2＼cjkstart血腫性病変における有用性について}

検査における有効性は no window であった 3 例を除 き,他の 15 例全例とも血腫の存在が認められた. 脳内血 腫例は脳実質と比べわずかに hyperechoic であったが, 脳実質外の血腫は慢性，急性にかかわらず hyperechoic あるいは hypoechoic の特徵を一様には示さなかった。 こ れについては骨による散乱反射音波の吸収減衰と，血腫 成分の性状による echogenesity の相違の双方が関係して いると考えられた。

また病巣側からの検索ではSTC (sensitivity time control）を調節してもなお noise 内に血腫の信号が埋も れてしまう場合があり，そのような症例では対側からの 検索で比較的明瞭に判別可能であった．慢性硬膜下血腫 の術後経過観察では，日常の回診時の使用で 2 例におい て血腫再貯留を CT scan 施行前に観察することが可能 であった。このことは当該機器の有用性を如実に示すも のと考えられた.

\section{4-3＼cjkstart血管性病变における有用性について}

脳動静脈奇形例では 2D-Doppler 画像上 nidus 内の血 流が順・逆両方向性の成分をもった渦巻く塊として描出 されることが本疾患の特徵であり，本法の画像診断能力 上もつとも有用であると考えられた。ささら，nidusが描 出されない場合でも Doppler sonogram を併用すること で，シャント血流の多寊に応じた主幹動脈の血流パタン の異常も観察することができ，血管性病変の存在が推定 できた。椎骨動脈合流部付近までの血管系の病変には Doppler sonogram が極めて有効で, 乱流等を明確に観察 できた.

\section{4-4小児例における有用性について}

小児科領域においてはすでに大泉門を通しての超音波 画像診断が汎用されている。しかし，本法は大泉門を介 さず経頭蓋的に検索可能であり，有効症例は飛躍的に拡 大される. 特に小児はその解剖学的特徴として成人に比 して骨が薄く，ほとんどの症例で 2D-Doppler 画像上主 幹動脈の第 2 区域まで描出・追跡が可能であった。実地 臨床上も，小児においては CT scan, MRI 等の検查時の 鎮静が問題となっているが，本法は熟練した検者が施行 する限り，短時間に多くの情報を無侵襲に得ることがで き, 今後の超音波機器利用の方向性を示すものと考える. 


\section{4-5 将来像の展望}

経頭蓋の頭蓋内検索に扔ける最大の問題点は骨組織の 透過性である，骨組織による音波エネルギーの減衰は極 めて大きく, 約 $45 \mathrm{~dB} / \mathrm{cm} / \mathrm{MHz}$ とされている15116). した がって $4 \mathrm{~mm}$ を越える骨を通しての検索時には, 受波工 ネルギーは送波エネルギーの $1 \%$ 以下にまで減衰してし まう。この減衰した音波エネルギーを電気的に増幅を行 なって画像を構成した場合, 画像のコントラストが付き にくく false negative を増やすこととなる. 本検索でも高 齢女性の髄膜腫例では, これまで術中画像所見で観察さ れたほど腫瘍と脳実質の階調に差が生じず，判別困難な 場合が存在した。

TCD 法による頭蓋内検索に関して Ackermann ら ${ }^{17)}$ は, 加齢による骨肥厚が最も検出率を低下させる原因で あるとし，また永井ら ${ }^{18)}$ は骨の厚さ以外に血流速度その ものが検出率に影響すると考察している. しかし, 今回 の検索ではCT scan上骨厚が比較的薄いにもかかわら ず, 頭蓋腔内の描出不可能な例も存在し, 超音波の伝搬 減衰の吸収・散乱については骨組織以外にも側頭筋を主 とした組織構成蛋白および体脂肪も大きな要因であると 考えられた. さらに, 一部症例で deep Sylvian vein と思 われる低速性の定常流が観察された例や, 頭蓋内構造が 明瞭に観察される場合でも血流成分がとらえられなかっ た例もあり，血流速度そのものと考えるより血流自身の 持つ総散乱エネルギーと頭蓋内血管走行の方向による血 流ベクトルなど, 前記以外の多数の因子が絡み合ってい ると考えられた。

次に, 画像構成に扔いて分解能は検查の有効性を左右 する要点であるが19)-22), 今回の筆者の検索方法では B モードの扇形を用いるため走查方向分解能に最もアーチ ファクト混入の要素が多いと考えられた. そのため出来 うる限り扇形の中心部での検索を心掛けた。 また辺縁部 の画像は読影上注意が必要であった。

距離方向分解能についても, 筆者ら ${ }^{23)}$ が慢性硬膜下血 腫の術後残留血腫腔の厚さを計測した際に, 脳表面と頭 蓋骨内板との間での多重反射やサイドローブによる虚像 が観察され, 血腫と脳組織との境界判別が困難であった 症例が存在した。本検索でも前頭部傍矢状部や頭頂部高 位, 前頭蓋底部の検查時には, 頭蓋骨に対する超音波の 入射角度を垂直に保つことが困難となり画像構成および 読影には特に注意が必要であった。

これまでの超音波画像における知見のほとんどは, 頭 蓋骨を除いた状況での所見が主である7)-10).しかし, 組織 による超音波の散乱状態は使用周波数によって変化し,
またこの散乱波は通常の反射波に比較して, 高周波成分 に偏りまた音圧は極めて低い。そのため遮蔽物の無い場 合には輝点の集合として hyperehoic に描出されるとさ れている組織の画像所見が, 実際には骨による透過状況 の変化によって著しく異なって描出される24).

以上のことを考慮すると, これまで手術時の頭蓋骨を 除いた画像状態についての報告は数多く発表されている が, 低周波数超音波による経頭蓋骨での画像所見には新 たな知見の積み重ねが必要であると考えられる.

現時点では未だ空間分解能が劣ること, 高齢者や女性 での画像構成が困難であること, 神経膠腫の描出に不確 実性を残すこと, echogenecityのみから病変組織の性質 までは推定できないこと 25)26) 等, 問題点は残されてい る.しかし, 本法は任意の断層面を連続的に検索可能で あり血流の存在を探知する能力は高く評価される. また 他の画像診断機器に比べてコンパクトでベッドサイドへ 移動しての検索が可能であり, リアルタイムの頭蓋内循 環動態が計測可能なことから病変部とその周囲の主要血 管の関係を術前, 術中, 術後に検査測定し, 血流保存の 予定・実践・確認を無侵襲で行なえることは極めて特徵 的である.

筆者の一連の知見は今後の超音波機器の方向性を示す 一つの里程標となるものと考える.

今後, 感度断層法等の応用により一層の描出能力の向 上を，また Spectral-Zero Shift-Crossing 法27)-29) 等の応用 により組織性状診断を可能にすることによって, 超音波 画像診断装置の有用性はますます高まると期待される.

\section{5. まटめ}

頭蓋内占拠性病変に対し経頭蓋超音波断層法による病 変検出の可否につき検討した。

1）超音波による頭蓋内描出率は，加龄によりまた同 世代では男性より女性で低下する傾向であった。

2) 髄膜腫 22 例中 13 例, 下垂体腺腫 12 例中 7 例, 脳 動静脈奇形 5 例中 3 例, 神経膠腫 8 例中 1 例, 頭蓋内の 血腫性病変 19 例中 15 例, 等の占拠性病変の診断に経頭 蓋超音波断層法が有用であった。

3) false negative の低減には測定の際に左右両側の側 頭面から Axial, Coronal 両方のスキャンで観察するこ とが必要であった。

4）大泉門閉鎖後の小児においても検索可能であっ た.

5）使用周波数と頭蓋骨の透過条件により各疾患の描 出は定型を示さないため他の付帯条件に留意することが 
重要であった。

以上の点に留意すれば, 超音波による頭蓋内画像診断 は他の診断機器に充分対抗しうるものと考えられた。

本研究は, 日本自転車振興会の援助を受けた。また本 論文の一部要旨は第 21 回日本神経放射線学会総会 $(1992$ 年 2 月, 秋田）および第 11 回日本脳・神経超音波研究会 総会（1992 年 5 月，久留米）にて発表した。

この稿を終えるにあたりご校閲いただいた東京慈恵会 医科大学脳神経外科中村紀夫教授, 同 ME 研究室古幡博 助教授に深謝致します。

\section{文献}

1) Leksell, H. Echoencephalography: detection of the intracranial complications following head injury. Acta Chir Scand 1956; 110:301-315.

2) Aaslid R, Markwalder TM, Nornes H. Non-invasive transcrasnial Doppler ultrasound recording of flow velocity in basal cerebral arteries. J Neurosurg 1982; 57: 769-774.

3) 土谷 隆, 矢板正弘, 山口武典, 長谷川泰弘, 尾前 豪. Transcranial real-time color flow Doppler による頭蓋内脳血 管の描出および血流速度測定の試み. 脳卒中 $1989 ; 11 ： 564$ -571 .

4) 古幡 博. 経頭蓋骨超音波断層法の新展開. Neurosonol $1989 ; 2: 8-15$.

5) 古平国泰, 藤代健太郎, 和田高士, 真家健一, 里井孝光, 月 山栄治, 福元 耕, 清水久盛, 三川秀文, 岡村哲夫. カラード プラ断層法による中大脳動脈血流速度の経頭蓋骨的絶対値計 測. 脈管学 $1990 ； 30 ： 1379-1386$.

6) Aaslid R. Transcranial Doppler examination techniques, 39 -59. In: Aaslid R. Transcranial Doppler Sonography, 4, Springer-Verlag, Wien, New York, 1986.

7) Rubin JM, Mirfakhraee M, Duda EE, Dohrmann GJ, Brown F. Intraoperative ultrasound examination of the brain. Radiology $1980 ; 137: 831-832$.

8) 益澤秀明, 神谷 博, 佐藤仁一. 脳神経外科に打ける術中超 音波診断; セク夕電子走查型超音波診断法の応用. Neurol Med Chir (Tokyo) 1981；21: 277-285.

9) 兵頭明夫, 水上公宏, 田澤俊明, 富樫 修. 開頭術中の超音 波診断. 脳神外科 $1984 ; 12: 311-318$.

10) 尾崎高志, 田邊治之, 楠瀬幹雄, 梶本宜永, 松島 滋. 開頭 術中に応用した超音波断層診断の経験; 主として頭部外傷例 と脳内出血例. 脳神外科 $1992 ; 20: 645-649$.

11) 古幡 博. 経頭蓋超音波カラー・ドプラ断層法の展望. Neurosonol 1991; 3: 133-141.
12) 阿部聡, 長谷川譲, 北島具秀, 和田崇文, 宮崎芳彰, 竹川 充, 長島弘泰, 中原成浩, 橋本卓雄, 中村紀夫, 古幡 博. 経頭蓋 超音波カラードプラ法による脳動脈瘤スクリーニングの可能 性とその PITFALLS. Neurosonol 1991；4: 96-105.

13) Becker G, Greiner K, Kaune B, Winkler J, Brawanski A, Warmuth-Metz M, Bogdahn U. Diagnosic and monitoring of subarachnoid hemorrhage by transcranial color-coded real-time sonography. Neurosurg 1991; 28: 814-820.

14) Bogdahn U, Becker G, Winkler J, Greiner K, Perez J, Meurers B. The transcranial color-coded real-time sonography in adults. Stroke, $1990 ; 21: 1680-1688$.

15) 日本超音波医学会編。超音波医学 (第 1 版), 医学書院 (東京 1966), 567.

16) Goss SA, Johnson RL, Dunn F. Comprehensive compilation of empirical ultrasonic properties of mammalian tissues. J Acoust Soc Am 1978; 64: 423-457.

17) Ackermann LV, Burke MW, Boulos RS, Patel S. Computed measures on computed tomograms of the head. Radiology $1982 ; 143: 115-120$.

18）永井秀政, 高家幹夫, 森竹浩三. TCD による頭蓋内血流検出 率に影響を及ぼす因子の検討。第 11 回日本脳・神経超音波研 究会抄録集, 久留米：日本脳・神経超音波研究会 $1992 ; 17$.

19）佐藤 茂. 超音波画像の基礎 (1) 超音波診断装置の原理. 臨 放線 1991；36：605-606.

20）佐藤 茂. 超音波画像の基礎 (2) 超音波診断装置の分解能. 臨放線 1991；36：715-716.

21）佐藤 茂. 超音波画像の基礎 (3) 超音波画像のアーチファク 卜. 臨放線 1991；36:839-840.

22）佐藤 茂. 超音波画像の基礎 (4) 超音波ドプラ法. 臨放線 1991；36：933-934.

23) 松本賢芳, 阿部 聡, 長谷川譲, 橋本卓雄, 中村紀夫. 経頭 蓋超音波ドプラ断層法 (TCD) によるベッドサイドにおける 頭蓋内血腫腔の描出の試み. 第 15 回日本脳神経 CT 研究会抄 録集, 広島：日本脳神経 CT 研究会 $1992 ; 129$.

24）内堀孝信, 神田良一, 高見沢欣也, 佐々木博, 古幡 博, 加 藤 征. 頭蓋骨エコーウインドウー部の超音波画像に対する 影響. 日超音波医会 49 回研究発表会講論集 1991，59；841 -842 .

25) de Vlieger $M$, Ridder HJ. Use of echoencechalography. Neurol $1959 ; 9: 216-223$.

26）大槻茂雄; 超音波組織性状診断. 第 10 回日本脳・神経超音波 研究会抄録集，広島：日本脳・神経超音波研究会 $1991 ; 20$.

27) Flax SW, Pelc NJ, Glover GH, et al. Spectral-characterization and attenuation measurements in ultrasound. Ultrasonic Imaging 1983; 5: 95-116.

28)伊東紘一, 安田是和, 鈴木修ほか. Spectral-Shift Zero-Crossing 法による周波数依存減衰に関する研究（第 1 報)。日超音波医会 49 回研究発表会講論集 1986：69-70.

29) 谷口信行, 伊東紘一, 倉松俊弘, 柳沢正義. Spectral-Shift Zero-Crossing 法による周波数依存減衰に関する研究; 新生 児・乳児の脳への応用. Neurosonol 1989;2:81-85. 